\title{
Construction and validation of an instrument for classifying nipple and areola complex lesions resulting from breastfeeding
}

\author{
Construção e validação de um instrumento de classificação das lesões mamilo-areolares decorrentes da amamentação
}

Construcción y validación de un instrumento para la clasificación de las lesiones areolares del pezón derivadas de la lactancia

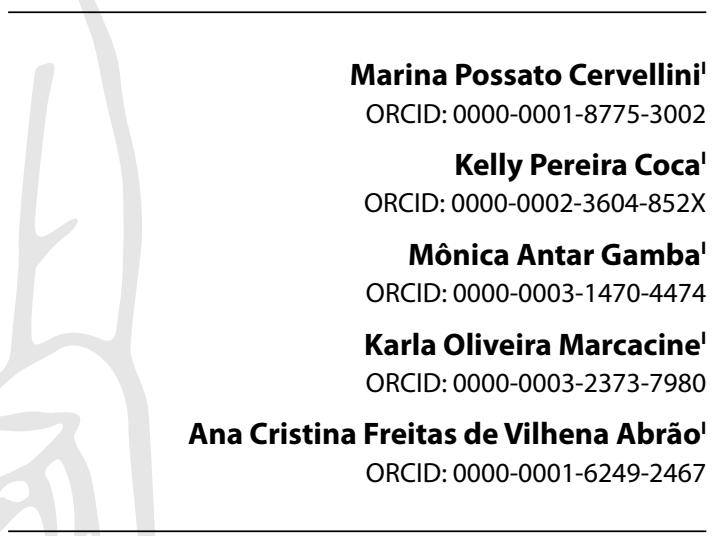

'Universidade Federal de São Paulo. São Paulo, São Paulo, Brazil.

How to cite this article:

Cervellini MP, Coca KP, Gamba MA, Marcacine KO, Abrão ACFV. Construction and validation of an instrument for classifying nipple and areola complex lesions resulting from breastfeeding. Rev Bras Enferm. 2022;75(1):e20210051. https://doi.org/10.1590/0034-7167-2021-0051

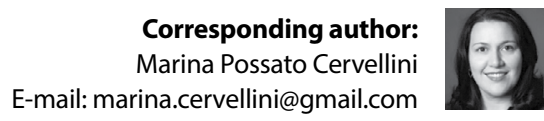

EDITOR IN CHIEF: Antonio José de Almeida Filho ASSOCIATE EDITOR: Álvaro Sousa

Submission: 02-22-2021

Approval: 05-05-2021

\begin{abstract}
Objectives: to construct and validate a classification of nipple and areola complex lesions resulting from breastfeeding, according to content and appearance. Methods: this is a methodological study, developed in four stages: operational definition, instrument construction, content and appearance validation. The Delphi technique and a Likert-type scale were used to validate content and appearance, through the participation of ten and sixteen judges, respectively. For analysis, Content Validity Index and Kappa Coefficient were applied. Results: Content Validity Index obtained an overall value of 0.93 and, for appearance, 0.94. Kappa values ranged between 0.46 and 1 . The high rates of agreement among judges demonstrated the quality of the proposed content validity. Conclusions: the Nipple and Areola Complex Lesions Classification Instrument developed obtained acceptable values of its indexes, proving to be valid in terms of content and appearance.

Descriptors: Breast Feeding; Wounds and Injuries; Nipples; Validation Study; Obstetric Nursing.
\end{abstract}

\section{RESUMO}

Objetivos: construir e validar uma classificação das lesões mamilo-areolares decorrentes da amamentação segundo conteúdo e aparência. Métodos: estudo metodológico, desenvolvido em quatro etapas: definição operacional, construção do instrumento, validação de conteúdo e de aparência. Utilizaram-se a técnica Delphi e a escala tipo Likert para a validação de conteúdo e de aparência, por meio da participação de dez e dezesseis juízes, respectivamente. Para análise, aplicou-se o Índice de Validade de Conteúdo e o Coeficiente Kappa. Resultados: o Índice de Validade de Conteúdo obteve valor global de 0,93 e, de aparência, 0,94. Os valores de Kappa variaram entre 0,46 e 1 . As altas taxas de concordância entre os juízes demonstraram a qualidade da validade de conteúdo proposta. Conclusões: o Instrumento de Classificação das Lesões Mamilo-Areolares desenvolvido obteve valores aceitáveis de seus índices, mostrando-se válido quanto ao conteúdo e aparência.

Descritores: Aleitamento Materno; Ferimentos e Lesões; Mamilos; Estudo de Validação; Enfermagem Obstétrica.

\section{RESUMEN}

Objetivos: construir y validar una clasificación de las lesiones pezón-areolares resultantes de la lactancia materna según su contenido y apariencia. Métodos: estudio metodológico, desarrollado en cuatro etapas: definición operativa, construcción del instrumento, validación de contenido y apariencia. Para validar contenido y apariencia se utilizó la técnica Delphi y la escala tipo Likert, mediante la participación de diez y dieciséis jueces, respectivamente. Para el análisis se aplicó el Índice de Validez de Contenido y el Coeficiente Kappa. Resultados: el Índice de Validez de Contenido obtuvo un valor global de 0,93 y, por apariencia, 0,94. Los valores de Kappa oscilaron entre 0,46 y 1. Las altas tasas de acuerdo entre los jueces demostraron la calidad de la validez del contenido propuesto. Conclusiones: el Instrumento de Clasificación de Lesiones Pezón-Areolares desarrollado obtuvo valores aceptables para sus índices, demostrando ser válido en términos de contenido y apariencia.

Descriptores: Lactancia Materna; Heridas y Traumatismos; Pezones; Estudio de Validación; Enfermería Obstétrica. 


\section{INTRODUCTION}

Nipple and areola complex lesions (NAL) resulting from breastfeeding have been presenting frequencies between $55 \%$ and $100 \%(1-3)$ among postpartum women and are generally related to the main causes of early weaning ${ }^{(3-4)}$, mainly due to association with pain and difficulties with proper infant latch ${ }^{(1,4)}$.

A systematic review study with 1,409 women identified a greater intensity of pain (6.2/10) in postpartum women with NAL, when compared to those without injury (2.7/10) in the first week after delivery, highlighting the importance of prevention and early diagnosis of injuries in the care of these women ${ }^{(5)}$.

Identifying NALs occurs during the clinical examination of postpartum women and, despite the clarity, by healthcare professionals, regarding the absence or presence of skin integrity in the nipple and areola complex region, there is no consensus on their classification, and the use of terminology "fissures" for any type of injury identified ${ }^{(6)}$.

When rethinking clinical practice, it is clear how much a detailed physical examination can contribute to identifying the type of injury and, consequently, the choice of appropriate treatment ${ }^{(6)}$. Furthermore, recognizing the affected structures, their shape, extension or depth, their thickness or consistency, among other observational variables, can expand and standardize the terminologies used to classify NALs.

It is observed that, despite the high frequencies of NALs ${ }^{(1-3)}$, few studies have explored the classification and form of assessment of NALs. Only three authors ${ }^{(7-9)}$ classify and describe the types and characteristics of NALs and differentiate them by size of the injured area ${ }^{(8-9)}$, degree of impairment ${ }^{(7,9)}$, loss or not of skin integrity ${ }^{(8-9)}$, defining them based on their relationship with the causal factor ${ }^{(7-8)}$. However, in addition to the lack of coverage of the lesions, only one validation study was developed to assess the agreement of the elaborated classification ${ }^{(9)}$.

Regarding the forms of NAL assessment, a review study identified 20 publications from 1986 to 2012 addressing this issue ${ }^{(6)}$. Among the assessment methods, the use of scales, indexes or scores, measurement of lesions, clinical examination, use of enlarged photographs and telephone call stood out ${ }^{(6)}$. Seven publications used previously developed instruments, namely: NTS ${ }^{(10)}$ (Nipple Trauma Score), Three-point Scale for Nipple Damage ${ }^{(11)}$, NAS ${ }^{(12)}$ (Nipple Attribute Score), NTI(13) (Nipple Trauma Index), the four-point scale for the assessment of erythema and fissure ${ }^{(14)}$ and the six-point scale for nipple damage ${ }^{(15)}$. Other publications, not included in this review, bring: the assessment scale for nipple damage ${ }^{(16)}$, the nipple damage severity scale ${ }^{(17)}$, the pain, bleeding and severity score scale $^{(18)}$ and the Nipple Trauma Indicator Instrument ${ }^{(2)}$. However, only one of these studies ${ }^{(10)}$ has a validation process and several authors ${ }^{(11-13,15-16)}$ have adapted an assessment pattern arising from other injuries ${ }^{(19)}$, not specifically from NALs.

All these studies brought different and important assessment models for a specific NAL or for nipple damage in a generalized way, however, in addition to the clear lack of consensus found among authors in the literature, the types of injury are poorly explored and the specific assessment and comprehensive is non-existent. Furthermore, there is no content validation study in the scientific literature that can define and classify them under the dermatological approach ${ }^{(6)}$.
Thus, the construction of a new classification, through a standardized, consensual and validated language, can bring important contributions to the recognition of NALs, favoring the diagnosis, specific treatment and continuity of nursing care, in addition to the possibility of bringing different outcomes to scientific research and the population's health, promoting and protecting the practice of breastfeeding.

\section{OBJECTIVES}

To construct and validate a classification of nipple and areola complex lesions resulting from breastfeeding, according to content and appearance.

\section{METHODS}

\section{Ethical aspects}

The study complied with Resolution 466 of December 2012, being sent to the Institutional Review Board of Universidade Federal de São Paulo and approved on November 14, 2017.

\section{Methodological design and study stages}

This is a methodological study, which used as a framework the psychometric procedures for the construction ${ }^{(20)}$ and validation ${ }^{(21-22)}$ of measuring instruments in health, developed in four stages: operational definition; classification instrument construction; application of content validation; appearance validation application.

In the first stage, the search for representative items of the construct under investigation was carried out, through three extensive literature reviews, in order to identify the main injuries currently classified and their definitions as well as the existence of a validated classification instrument on them.

The first review was carried out in the MEDLINE (Medical Literature Online), LILACS (Latin American and Caribbean Health Sciences) and PMC (PubMed Central) databases between October 2012 and February 2019. Chart 1 presents the searches performed in each database and the keywords and/or words used.

The second review was carried out in the same period, and the databases, for the searches, used the following keywords and/or words, as shown in Chart 2.

Chart 1 - Keywords and/or words used in the first review, São Paulo, São Paulo, Brazil, 2021

\begin{tabular}{|c|c|}
\hline Databases & Keywords or words \\
\hline MEDLINE & $\begin{array}{l}\text { 1. "nipples" [words] AND "sore" [words] } \\
\text { 2. "nipples" [words] AND "trauma" [words] } \\
\text { 3. "nipples" [words] AND "pain" [words] }\end{array}$ \\
\hline $\begin{array}{l}\text { PubMed } \\
\text { Central }\end{array}$ & $\begin{array}{l}\text { 1. "nipples/injuries" [mesh term] } \\
\text { 2. "nipples" [mesh term] AND "pain" [mesh term] } \\
\text { 3. "nipples" [mesh term] AND "sore" [words] } \\
\text { 4. "nipples/injuries" [mesh term] AND (evaluation OR } \\
\text { classification OR signs AND symptoms [mesh term] } \\
\text { OR treatment outcome [mesh term]) }\end{array}$ \\
\hline LILACS & $\begin{array}{l}\text { 1. "mamilos" [words] AND "dor" [words] } \\
\text { 2. "mamilos" [words] AND "lesões" [words] } \\
\text { 3. "mamilos" [words] AND"trauma" [words] }\end{array}$ \\
\hline
\end{tabular}


Chart 2 - Keywords and/or words used in the second review, São Paulo, São Paulo, Brazil, 2021

\begin{tabular}{|c|c|}
\hline Databases & Keywords or words \\
\hline MEDLINE & $\begin{array}{l}\text { 1. "estudos de validação" [type of publication] AND } \\
\text { "lesões" [subject descriptor] AND "mamilos" [words] } \\
\text { 2. "reprodutibilidade dos testes" [subject descriptor] AND } \\
\text { "feridas" [words] AND"mamilos" [words] } \\
\text { 3. "estudos de validação" [type of publication] AND "ama- } \\
\text { mentação" [words] } \\
\text { "estudos de validação como assunto" [subject descrip- } \\
\text { tor] AND"lesões" [subject descriptor] AND"mamilos" } \\
\text { [words] }\end{array}$ \\
\hline $\begin{array}{l}\text { PubMed } \\
\text { Central }\end{array}$ & $\begin{array}{l}\text { 1. "validation studies" [publication type] OR "validation } \\
\text { studies as topic" [mesh term] AND "questionnaires" } \\
\text { [words] AND "lesions" [words] AND "nipples" [words] } \\
\text { 2. "validation studies" [publication type] AND "lesions" } \\
\text { [words] AND "nipples" [words] }\end{array}$ \\
\hline LILACS & $\begin{array}{l}\text { 1. "feridas" [words] AND"confiabilidade" [words] AND } \\
\text { "mamilos" [words] } \\
\text { 2. "reprodutibilidade dos testes" [subject descriptor] AND } \\
\text { "feridas" [words] AND"mamilos" [words] }\end{array}$ \\
\hline
\end{tabular}

The third review specifically sought to answer the following question: how are NALs described in dermatological glossaries? The searches were carried out in the collections of Libraries of Universidade Federal de São Paulo (UNIFESP), Universidade Estadual de Campinas (UNICAMP), Universidade de São Paulo (USP), and Universidade Estadual Paulista (UNESP), through its search portals, from 1990 to 2018. The words used in the search portals were dermatology atlas, clinical dermatology, and dermatology or medicine guidelines.

In the second stage, there was the construction of a classification composed of three domains (D): D1- Definition of NALs resulting from the practice of breastfeeding; D2- NALs without skin barrier disruption; D3 - NALs with skin barrier disruption; eight items (I): I1 - Definition of NAL; 12 - Red Erythema or Redness; I3 - Ecchymosis or Blemish;14-Vesicle; I5 - Edema; I6 - Crust; 17-Erosion; I8-Ulceration.

Then, the domains and items were organized through the morphological characteristics of the skin found in the dermatological glossaries ${ }^{(23-27)}$ and objectivity standards of nominalist dermatological school ${ }^{(28)}$, with the purpose of identifying the lesion at the time of observation, including: anatomical location, shape, color, presence or absence of liquid content, changes in thickness or consistency, tissue loss or continuity solution, type of injured tissue and extension or depth.

After this first content construction, several discussions and focal meetings took place between a group of four researchers with expertise in teaching, research, and care in obstetrics and breastfeeding and/or dermatology and injury care, to clarify controversial points and define, with greater precision: the main lesions observed in clinical practice and the best way to describe these lesions in accordance with the dermatological glossaries.

Then, a dermatology specialist was selected based on her expertise and resume on Currículo Lattes platform, to assess the classification elaborated (pre-test), which was sent electronically, after accepting the invitation to participate in the research and signing the Informed Consent Form (ICF). After this assessment, a new meeting was held between the researchers, reaching a final proposal to submit to content validation.
This process of development and construction of a new measurement instrument, through literature review and the clinical experience of focus groups, whether through interviews, observation of practical experience or consensus meetings, is widely used in studies of current literature ${ }^{(29-34)}$.

In the third and fourth stage, material validation was carried out by two committees of experts in the areas of interest. For stage 3, judges were from the field of dermatology and, for stage 4 , from the field of breastfeeding. After analyzing the data and indexes obtained, the latest version of the Instrument was written.

\section{Population or sample; inclusion and exclusion criteria}

There is no consensus in the literature regarding the number of judges needed for a validation study ${ }^{(22,35-36)}$. A literature review showed that some authors recommend a committee composed of at least 5 and at most 10 professionals with clinical experience in the field and working at the time of the research ${ }^{(22)}$. Some studies that address content validation selected from 5 to 17 experts for the validation stage ${ }^{(29-31,33,36-37)}$.

In this study, participants were identified based on their expertise and their resumes found on Currículo Lattes platform. In the third stage, 38 professionals were considered eligible, of which 12 agreed to participate in the study. The following were used as selection criteria: being physicians and/or nurses, dermatologists and/or stomatherapists, masters and/or doctors with expertise in dermatology/or stomatherapy and care for injuries, with at least, five years of clinical experience in the field. In the fourth stage, 23 professionals were considered eligible, of which 16 agreed to participate in the study. Healthcare professionals, specialists in the field of neonatology and/or obstetrics and active in direct assistance to nursing mothers, whether in an educational institution, hospital or outpatient sector, were included.

\section{Study protocol}

Data collection took place electronically in the following order: identification of judges, invitation to participate and submission of the instrument for analysis upon acceptance and signature of the ICF. The data collection instrument contained judges' characterization and a Likert-type scale for assessing the items with filling instructions.

Content and appearance validation took place through the Delphi technique, which consisted of sending the data collection instrument in rounds, which could extend up to 3 and/or end with the achievement of the determined minimum agreement ${ }^{(32-33)}$. This strategy has been widely used in the field of health ${ }^{(32-33,37-38)}$ to obtain a maximum consensus from a group of experts on a given topic, especially when unanimity of opinion does not exist due to the lack of scientific evidence ${ }^{(20)}$. For this assessment, a Likert-type scale was adopted with a score of 1 to 4 , and, in the case of non-agreement, a space for comments and suggestions was reserved.

Stage 3 judges were asked to assess item agreement in relation to three dimensions or variables, clarity (text comprehension), scope (breadth of the phenomenon studied) and relevance 
(adequacy to the proposed objectives). In stage 4, assessment took place in relation to the dimension of clarity (easiness of reading and/or understanding of the text), through the instrument judgment by the target audience.

\section{Analysis of results, and statistics}

Current studies on the development of measurement instruments demonstrate that a widely used approach to assess content and/or appearance validity is Content Validity Index (CVI) by item, by dimension or globally, adopting a value minimum to reach agreement, which can range from 0.70 to $0.80^{(30-35,37-44)}$.

The results of this study were tabulated by double typing, using the Excel program (Microsoft, USA). CVI was calculated by adding the items marked as " 3 " or " 4 " and divided by the total number of responses. A minimum value of 0.80 was adopted to reach agreement and items that presented indexes below the minimum would be reformulated according to judges' opinion $^{(30-35,38,43-44)}$.

The overall CVI by dimension was also adopted, which represents the average of content validation indexes for a given dimension, calculated by the sum of all CVIs divided by the number of items. The global CVI, when possible, represents the instrument's global CVI, i.e., the average of CVIs for all items and dimensions, calculated by the sum of all overall CVIs divided by the number of dimensions ${ }^{(30,41)}$.

As it is an important supplement for CVI, as it provides information on the degree of agreement beyond chance ${ }^{(31,38,42)}$, The Kappa coefficient was also calculated with the help of a statistic, using the statistical software STATA 12 (Stata\#Corp, USA), which considered a significance level of $5 \%$ and an acceptance level of moderate to perfect agreement. Their values can range from 0 to 1 , with perfect agreement from 1 to 0.81 , substantial, from 0.61 to 0.80 , moderate, from 0.41 to 0.60 , weak, from 0.21 to 0.40 , mild, from 0.0 to 0.20 and absent agreement less than $0^{(45)}$.

Figure 1 demonstrates the methodological course stages of this study.

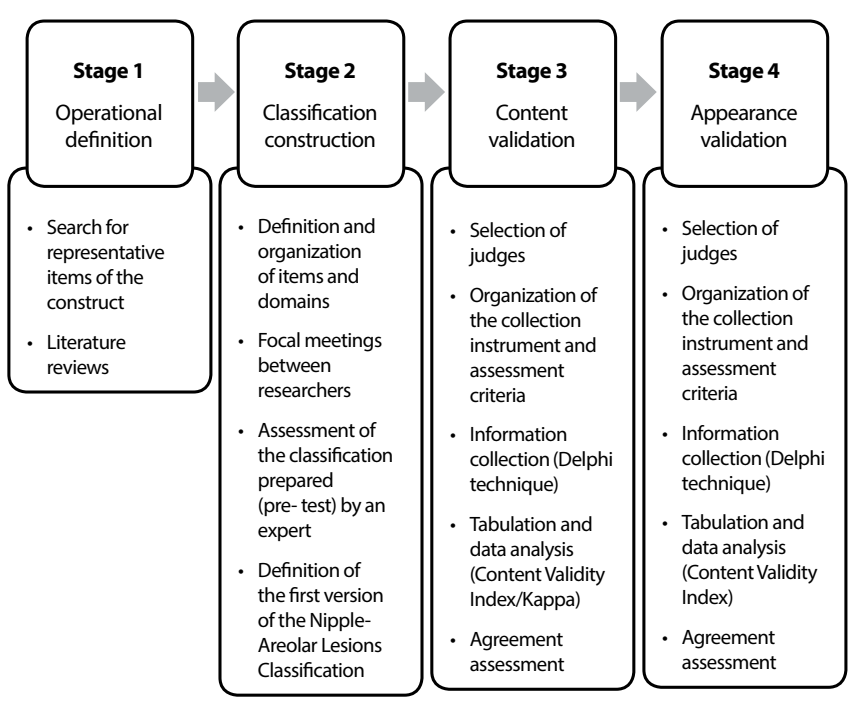

Figure 1 - Methodological path, construction and validation stages, São Paulo, São Paulo, Brazil, 2021

\section{RESULTS}

\section{Nipple and Areola Complex Lesions Classification Construction}

The construction process was carried out from June to October 2017. After analyzing the three literature reviews, meetings with the group of researchers and expert assessment, the concept of definition, classification and morphological description of NALs were elaborated.

In the first review, 300 publications were identified from October 2012 to February 2019 and 21 comprised the final sample. Another 20 studies were added to this sample, from 1986 to 2012 , from a previous review ${ }^{(6)}$. Thus, it was possible to verify, in the world literature, which are the definitions and classifications of NALs as well as part of their characterization.

In the second review, 148 publications were identified from October 2012 to February 2019, but no publication was found that addressed the development and/or validation of a classification instrument for NALs arising from breastfeeding. The previous review also did not identify publications ${ }^{(6)}$. With this result, it was possible to affirm that there is no validated instrument that defines, classifies and characterizes NALs.

In the third review, 40 reference books in dermatology were identified, from 1990 to 2018, in the collections of the four researched universities, applying the selection criteria, leaving five references. With the analysis of dermatological glossaries and identification of NALs among the elementary lesions, it was possible to describe the best form of recognition and characterization of NALs.

With the result of the reviews categorized into tables and the clinical experience of the group of researchers in the care of skin lesions and NALs, the first version was built.

NALs were defined as changes in the nipple and areola complex skin, identified through changes in color, thickness, fluid content or tissue loss.

NALs were classified as: erythema (lesion with a change in the natural skin color to red or pink in a given nipple and areola complex area); ecchymosis or blemish (injury with a change in the skin's natural color to purplish or brown in a particular nipple and areola complex area); edema (lesion with modification of the skin's natural thickness due to accumulation of fluid, with the presence of distension, shine and skin stiffness); vesicle (lesion with modification of the skin's natural liquid content, through the presence of circumscribed elevation, filled with clear, serous liquid or white content (milk), measuring up to $0.5 \mathrm{~cm}$ in diameter and located on the nipple surface); fissure (injury with loss of skin integrity, linear in shape, which may present with bleeding or serous fluid); erosion or exulceration (injury with loss of skin integrity in a circumscribed shape, which may present with bleeding or serous fluid. Of varied length and depth, being more superficial (excoriation) or deeper (erosion), crust (lesion formed in an area of tissue loss resulting from the concretion of serous fluids or blood, light yellow or dark red).

Also, during the construction process, ulceration was excluded and the crust was included. It was understood that ulceration did not represent a NAL, as it represents a chronic lesion with circumscribed loss of epidermis and dermis, which can reach deep 
tissues ${ }^{(27)}$. The inclusion of the crust was due to its recognition in the literature and its constant observation in clinical practice.

\section{Nipple and Areola Complex Lesions Classification Validation}

Content validation took place from December 2017 to June 2018. Of the 38 invitations sent to the judges, 12 agreed to participate in the survey, with 10 participating in the first round of responses and 8 in the second. Participants were women with a degree in nursing, minimum master's degree (three masters and seven doctors) and professional experience from 14 to 35 years in the field of dermatology.

After analyzing the data from the first round, using the Delphi technique, in the three dimensions analyzed (clarity, scope and relevance), a CVI between 0.90 and 1.00 was obtained for the definition of NAL and its types: erythema, ecchymosis, edema, vesicle, fissure and erosion. Only the crust had a CVI between 0.70 and 0.80 , with this, this item was reformulated, and the Instrument, sent back.

After the second round, all items received, in the three variables analyzed, a CVI from 0.87 to 1.00 , with no need for a third round.

The Kappa coefficient demonstrated the agreement obtained for the three dimensions (clarity, scope and relevance) per item and in a dichotomized way. At that time, for the calculation of this coefficient, value 1 was applied for answers 3 and 4, and value 0 for answers 1 and 2. Perfect and moderate Kappa was obtained, with no need to recalculate the coefficient due to absence weakly agreeable.

Next, Table 1 is presented, which highlights the instrument (first and third versions) and the indexes found.

Once agreement was reached, appearance validity was continued. This stage was carried out in July 2018. Of the 23 invitations sent, 16 judges agreed to participate in the survey and completed the first round of responses. Participants were women, one with a degree in medicine and a specialty in pediatrics and fifteen with a degree in nursing and a specialization in obstetrics. Among these, three had a master's degree and three a PhD degree. The average length of professional experience in the field of breastfeeding was ten years, ranging between 3 and 36 years.

After analyzing the results, a CVI for clarity and per item of 0.94 was obtained for definition, fissure and erosion, and 1.00 for erythema, ecchymosis, edema, vesicle and crust, with no need for second round of responses. The overall CVI for clarity was 0.98 .

After text corrections, the final version of the classification was named ILMA, and is presented in Chart 3.

Table 1 - Nipple and Areola Complex Lesions Classification resulting from breastfeeding, under a dermatological approach and content validation stage indexes, São Paulo, São Paulo, Brazil, 2021

\begin{tabular}{|c|c|c|c|c|c|}
\hline \multirow{2}{*}{ First version } & \multicolumn{3}{|c|}{ Content Validity Index } & \multirow{2}{*}{ Kappa } & \multirow{2}{*}{$\begin{array}{l}\text { Third version } \\
\text { (after } 2^{\text {nd }} \text { round of answers) }\end{array}$} \\
\hline & Clarity & Scope & Relevance & & \\
\hline \multicolumn{6}{|l|}{$\begin{array}{l}\text { D1. Nipple and areola complex injuries resulting } \\
\text { from the practice of breastfeeding }\end{array}$} \\
\hline $\begin{array}{l}\text { 1. Definition: changes in the nipple and areola } \\
\text { complex skin, identified by (...) }\end{array}$ & 0.90 & 0.90 & 0.90 & 1.00 & $\begin{array}{l}\text { 1. Definition: changes in the nipple and areola } \\
\text { complex characteristics skin during (...) }\end{array}$ \\
\hline \multicolumn{6}{|l|}{$\begin{array}{l}\text { D2. Nipple and areola complex lesions without skin } \\
\text { barrier disruption }\end{array}$} \\
\hline $\begin{array}{l}\text { 2. Erythema: lesion with change in the natural skin } \\
\text { color for (...) }\end{array}$ & 1.00 & 1.00 & 1.00 & 1.00 & $\begin{array}{l}\text { 2. Erythema: lesion characterized by the change } \\
\text { from the natural skin color to red (...) }\end{array}$ \\
\hline $\begin{array}{l}\text { 3. Ecchymosis or Blemish: lesion with change in the } \\
\text { natural skin color to purplish or (...) }\end{array}$ & 1.00 & 1.00 & 1.00 & 1.00 & $\begin{array}{l}\text { 3. Ecchymosis: lesion characterized by the change } \\
\text { from the natural skin color to purple (...) }\end{array}$ \\
\hline $\begin{array}{l}\text { 4. Edema: lesion with modification of the skin's } \\
\text { natural thickness due to fluid accumulation (...) }\end{array}$ & 1.00 & 1.00 & 1.00 & 1.00 & $\begin{array}{l}\text { 4. Edema: modification of the skin's natural thickness } \\
\text { due to accumulation of fluid (plasma) in the dermis } \\
\text { or (....) }\end{array}$ \\
\hline $\begin{array}{l}\text { 5. Vesicle: lesion with modification of the skin's } \\
\text { natural liquid content through the presence of a } \\
\text { raised shape (...) }\end{array}$ & 0.90 & 0.90 & 0.90 & 1.00 & $\begin{array}{l}\text { 5. Vesicle: lesion with modification of the skin's } \\
\text { natural liquid content, identified by the presence } \\
\text { of a bulge (...) }\end{array}$ \\
\hline \multicolumn{6}{|l|}{$\begin{array}{l}\text { D3. Nipple and areola complex lesions with skin } \\
\text { barrier disruption }\end{array}$} \\
\hline $\begin{array}{l}\text { 6. Fissure: lesion with loss of skin integrity, } \\
\text { shape (...) }\end{array}$ & 0.90 & 1.00 & 0.90 & 0.46 & $\begin{array}{l}\text { 6. Fissure: linear and narrow shape continuity } \\
\text { solution (...) }\end{array}$ \\
\hline $\begin{array}{l}\text { 7. Erosion or Exulceration: circumscribed lesion } \\
\text { with loss of skin integrity (...) }\end{array}$ & 0.90 & 0.90 & 0.90 & 1.00 & $\begin{array}{l}\text { 7. Erosion: solution of continuity of circumscribed or } \\
\text { irregular shape, with loss of epidermis (...) }\end{array}$ \\
\hline $\begin{array}{l}\text { 8. Crust: lesion formed in an area of tissue loss } \\
\text { resulting from (...) }\end{array}$ & 0.87 & 0.87 & 0.87 & 0.58 & $\begin{array}{l}\text { 8. Crust: result of the drying of the serous, } \\
\text { purulent exudate or (...) }\end{array}$ \\
\hline Overall Content Validity Index & 0.93 & 0.94 & 0.93 & & \\
\hline Global Content Validity Index & \multicolumn{4}{|c|}{0.93} & \\
\hline
\end{tabular}


Chart 3 - Nipple and Areola Complex Lesions Classification Instrument, São Paulo, São Paulo, Brazil, 2021

\begin{tabular}{|c|c|c|}
\hline \multicolumn{3}{|r|}{ Nipple and Areola Complex Lesions Classification Instrument } \\
\hline $\begin{array}{l}\text { Definition of } \\
\text { nipple and areola } \\
\text { complex lesions }\end{array}$ & \multicolumn{2}{|r|}{$\begin{array}{l}\text { Changes in the characteristics of the nipple and areola complex skin during breastfeeding, identified through changes in color, } \\
\text { thickness, fluid content, or tissue loss. }\end{array}$} \\
\hline \multirow{4}{*}{$\begin{array}{l}\text { Nipple and areola } \\
\text { complex lesions } \\
\text { without skin } \\
\text { barrier disruption }\end{array}$} & Erythema & A lesion characterized by a change in the skin's natural color to red or pink in a particular nipple-areola area. \\
\hline & Ecchymosis & A lesion characterized by a change in the skin's natural color to purple or brown in a particular nipple-areola area. \\
\hline & Edema & $\begin{array}{l}\text { Modification of the skin's natural thickness due to accumulation of fluid (plasma) in the dermis or hypodermis, } \\
\text { with the presence of distension, shine and/or skin stiffness. }\end{array}$ \\
\hline & Vesicle & $\begin{array}{l}\text { A lesion with modification of the skin's natural liquid content, identified by the presence of a bulge filled with } \\
\text { clear (serous) or white (milky) liquid, measuring up to } 0.5 \text { centimeters in diameter, located on the nipple surface. }\end{array}$ \\
\hline \multirow{3}{*}{$\begin{array}{l}\text { Nipple and areola } \\
\text { complex lesions } \\
\text { with disruption of } \\
\text { the skin barrier }\end{array}$} & Fissure & Linear and narrow continuity solution, which may present with bleeding or serous fluid of variable depth. \\
\hline & Erosion & $\begin{array}{l}\text { Continuity solution of circumscribed or irregular shape, with loss of epidermis or dermis, which may present } \\
\text { with bleeding or serous fluid. When it occurs more superficially, it is called excoriation. }\end{array}$ \\
\hline & Crust & $\begin{array}{l}\text { Result of the drying of serous, purulent, or hematic exudate from a previously injured area. It can be light yellow, } \\
\text { brown or dark red. }\end{array}$ \\
\hline
\end{tabular}

\section{DISCUSSION}

This is the first instrument validated for content and appearance, with definition and classification of NALs, under a dermatological approach.

Current literature identifies the participation of a group of experienced judges as essential in content assessment ${ }^{(20-22,29-35)}$. It is recognized, in this study, that the judges contributed to content adequacy, by suggesting significant adjustments and/or additions to the proposed classification, as well as their expertise and qualification, and enabled a critical and rigorous analysis of sentences.

Regarding the dimensions analyzed, the result of an overall CVI for clarity and relevance of 0.93 demonstrated agreement in the understanding of the text and adequacy to the proposed objectives; an overall CVI of 0.94 for coverage indicated agreement with the breadth of the phenomenon studied, which may indicate the real specificity of NALs resulting from breastfeeding.

Regarding the instrument's global CVI with a result of 0.93 , the quality of the instrument's content validity is recognized. This high rate of agreement was achieved because the process of operational definition and instrument construction took place rigorously, seeking representation through scientific evidence in three literature reviews, consensus among researchers with expertise in the studied topic and pre-assessment by the dermatology specialist.

No items were eliminated, but some discussions emerged with judges' suggestions. Regarding erythema, this lesion can be seen at the beginning of breastfeeding. Even without disrupting skin integrity, the pressure exerted by newborns' suction can change the skin's natural color to red. After the end of feedings and between feedings, the skin may return to its natural color, with erythema being considered transitory, even if found around cracks or crusts, as shown in the literature ${ }^{(9)}$.

Ecchymosis, also known and illustrated as purpura ${ }^{(9)}$ or purpuric lesion ${ }^{(23-27)}$, can be observed right at the beginning of breastfeeding, around the first or second day of breastfeeding ${ }^{(9)}$. At this time, the nipple and areola complex skin is purplish or brown, a change usually caused by blood leakage in this region ${ }^{(9,23-27)}$.
As for edema, this lesion may appear on the third day of breastfeeding, usually associated with the inflammatory phase of tissue damage and increased pain ${ }^{(14)}$. In the nipple and areola complex region, accumulation of plasma in the dermis and the distension of the boundary lines between the nipple papillae may show the presence of fissures; however, the skin's shine and rigidity characterize the presence of inflammatory edema, as illustrated by some authors ${ }^{(9,14)}$.

Regarding the vesicle characterization, all suggestions were accepted and changes were made, in order to provide greater clarity in the lesion definition, as presented in dermatological glossaries ${ }^{(23-27)}$, without losing the nipple and areola complex tissue specificity.

During breastfeeding, this type of lesion can occur following an edema ${ }^{(14,46)}$ and is usually noticed by the presence of a protrusion filled with serous fluid, sometimes lighter, sometimes more reddish, as presented in the literature ${ }^{(10,46)}$. Moreover, one can see the occurrence of this lesion, filled with breast milk, at different times of breastfeeding.

The fissure, the type of lesion most commonly observed in clinical practice, begins with the involvement of the most superficial layer of the skin (epidermis), which may deepen to the dermis, depending on the maintenance of the causal factor or lack of adequate coverage. Some authors point to its onset around the third to the fifth day of breastfeeding ${ }^{(9,14)}$, a period that coincides with the transition of tissue damage from the inflammatory to the proliferative phase ${ }^{(47)}$.

The choice of keeping excoriation as a more superficial type of erosion and abolishing the use of the term exulceration was made not only by judges' suggestions, but also by NALs' clinical evolution. Generally, excoriation is observed in the first days of puerperium ${ }^{(14,46)}$ and erosion between the fifth and seventh day ${ }^{(14,46)}$. At that time, breastfeeding episodes are more frequent; possibly, with continuity of trauma and/or absence of therapeutic measures, the lesion worsens, which can also be noticed by the presence of bleeding, or serous fluid (excoriation) ${ }^{(46)}$, or exposure of a moist layer by dermis disruption (erosion) ${ }^{(46)}$. 
As for the crust, this lesion is defined in dermatological glossaries as an elementary lesion ${ }^{(23-24,26)}$, loss, or repair tissue ${ }^{(27)}$. For scholars in pathology ${ }^{(47)}$, crust is described as a result of the blood clot dehydration on the wound surface. This clot is formed by fibrin, necrotic debris and exudate, generating light yellow, brown, light red and dark red variations in the crust ${ }^{(47)}$.

In clinical practice in breastfeeding, scab is very common among nursing mothers. What is observed at the time of clinical examination is a crust and no longer the area that was previously injured (or the elementary secondary lesion that occurred), and it is understood, therefore, that, as they are different injuries, care can also be differentiated.

To assess whether the agreement observed among judges was not random, and in order to ensure that such agreement was actually attributed to the classification's content properties, the Kappa coefficient calculation was applied, in a complementary way. Statistical analysis revealed perfect agreement for definition, erythema, ecchymosis, edema, vesicle and erosion in the three dimensions, reinforcing the quality of content due to smaller number of comments received and fewer responses 1 or 2 . The moderate agreement for crack and crust is related to the largest number of suggestions received.

In appearance validation, the terms "change in thickness" or "liquid content", from the definition of NALs item, were judged by two breastfeeding specialists as unclear and difficult to interpret. This may have occurred, due to a probable theoretical-practical distancing of these professionals with the dermatological terminology ${ }^{(23-27)}$. Likewise, the term "continuity solution" was not clear for the identification of a fissure or erosion for two specialists, probably due to the specific terminology ${ }^{(23-27)}$ little used in the field of breastfeeding.

However, the range of CVI per item from 0.94 to 1.00 demonstrated the ease of reading sentences and characterizing the lesions. An overall CVI reach of 0.98 for clarity demonstrated the understanding of the text and content presented to the target audience.

\section{Study limitations}

The reliability and clinical validation of items in this classification need to be verified in addition to the contributions of expert opinion consensus. Such validation will increase the specificity of healthcare professionals' practices, diagnosis and treatment of NALs.

\section{Contributions to nursing, health, and public policies}

The ILMA presents a validated classification, with high quality of its content properties, which enables the recognition of NALs, becoming an information technology tool to equip nursing care and assist, even in fulfilling the professional practice of this category.

\section{CONCLUSIONS}

This study enabled the construction of a classification instrument for NALs (ILMA), under a dermatological approach and its validation, according to content and appearance. The high validity indexes found among dermatology and/or injury care and breastfeeding experts indicated that this instrument can be applied in the recognition of NALs resulting from breastfeeding.

\section{REFERENCES}

1. Dias JS, Vieira TO, Vieira GO. Factors associated to nipple trauma in lactation period: a systematic review. Rev Bras Saude Matern Infant. 2017;7(1):27-42. https://doi.org/10.1590/1806-93042017000100003 Portuguese.

2. Cirico MOV, Shimoda GT. Oliveira RNG. Healthcare quality in breastfeeding: nipple trauma indicator implementation. Rev Gaucha Enferm. 2017 Feb 37(4):e60546. https://doi.org/10.1590/1983-1447.2016.04.60546

3. Thompson R, Kruske S, Barclay L, Linden K, Gao Y, Kildea S. Potential predictors of nipple trauma from an in-home breastfeeding programme: a crosssectional study. Women Birth. 2016;29(4):336-44. https://doi.org/10.1016/j.wombi.2016.01.002

4. Carreiro JA, Francisco AA, Abrão ACFV, Marcacine KO, Abuchaim ESV, Coca KP. Breastfeeding difficulties: analysis of a service specialized in breastfeeding. Acta Paul Enferm. 2018;31(4):430-8. https://doi.org/10.1590/1982-0194201800060

5. Coca KP, Amir LH, Alves MRS, Barbieri M, Marcacine KO, Abrão ACFV. Measurement tools and intensity of nipple pain among women with or without damaged nipples: a quantitative systematic review. J Adv Nurs. 2019;75(6):1162-72. https://doi.org/10.1111/jan.13908

6. Cervellini MP, Gamba MA, Coca KP, Abrão ACFV. Injuries resulted from breastfeeding: a new approach to a known problem. Rev Esc Enferm USP. 2014;48:346-56. https://doi.org/10.1590/s0080-6234201400002000021

7. Vinha V. O livro da amamentação. São Paulo: CLR Balieiro; 1999. Traumas mamilares (ferimentos): prevenção e cuidados; p. 45-54.

8. Biancuzzo M. Sore nipples: prevention and problem-solving. Herndon: WMC Worldwide; 2000.

9. Nakamura M, Asaka Y, Ogawara T, Yorozu Y. Nipple Skin Trauma in breastfeeding women during postpartum week one. Breastfeeding Med. 2017;13(17):479-84. https://doi.org/10.1089/bfm.2017.0217

10. Abou-Dakn M, Fluhr JW, Gensch M, Wöckel A positive effect of HPA lanolin versus expressed breastmilk on painful and damaged nipples during lactation. Skin Pharmacol Physiol. 2011;24(1):27-35. https://doi.org/10.1159/000318228.

11. Livingstone V, Willis CE, Berkowitz J. Staphylococcus aureus and sore nipples. Canad Fam Physic. 1996;42:654-9. https://doi. org/10.1177/089033449901500315

12. Brent N, Rudy SJ, Redd B, Rudy TE, Roth LA. Sore nipples in breast-feeding women: a clinical trial of wound dressings vs conventional care. Arch Pediatr Adolesc Med. 1998;152(11):1077-82. https://doi.org/10.1001/archpedi.152.11.1077 
13. Duffy EP, Percival P, Kershaw E. Positive effects of an antenatal group teaching session on postnatal nipple pain, nipple trauma and breast feeding rates. Midwifery. 1997;13(4):189-96. https://doi.org/10.1016/s0266-6138(97)80005-8

14. Ziemer MM, Pigeon JG. Skin changes and pain in the nipple during the 1st week of lactation. J Obstet Gynecol Neonatal Nurs. 1993;22(3):247-56. https://doi.org/10.1111/j.1552-6909.1993.tb01806.x

15. Herd B, Feeney JG. Two aerosol sprays in nipple trauma. Practit. 1986;230(1411):31-8.

16. Amir LH, Lumley J, Garland SM. A failed RCT to determine if antibiotics prevent mastitis: cracked nipples colonized with staphylococcus aureus: a randomized treatment trial. BMC Pregnancy Childbirth. 2004;11:1-4. https://doi.org/10.1186/1471-2393-4-19

17. Kuşcu NK, Koyuncu F, Laçin S. Collagenase treatment of sore nipples. Int J Gynaecol Obstet. 2002;76(1):81-2. https://doi.org/10.1016/ s0020-7292(01)00550-1

18. Marrazzu A, Sanna MG, Dessole F, Capobianco G, Piga MD, Dessole S. Evaluation of the effectiveness of silver-impregnated medical cap fot topical treatment of nipple fissure of breastfeeding mothers. Breastfeeding Med. 2015;10(5):232-8. https://doi.org/10.1089/bfm.2014.0177

19. Lazarus GS, Cooper DM, Knighton DR, Margolis DJ, Pecoraro RE, Rodeheaver G, Robson MC. Definitions and guidelines for assessment of wounds and evaluation of healing. Arch Dermatol. 1994;130(4):489-93. https://doi.org/10.1001/archderm.1994.01690040093015

20. Coluci MZO, Alexandre NMC, Milani D. Construction of measurement instruments in the area of health. Ciênc Saúde Colet. 2015;20(3):92536. https://doi.org/10.1590/1413-81232015203.04332013

21. Cunha CM, Almeida Neto OP, Stackfleth R. Principais métodos de avaliação psicométrica da validade de instrumentos de medida. Rev Atenc Saúde. 2016;14(47):75-83. https://doi.org/10.13037/ras.vol14n47.3391

22. Souza AC, Alexandre NMC, Guirardello EB. Propriedades psicométricas na avaliação de instrumentos: avaliação da confiabilidade e da validade. Epidemiol Serv Saude. 2017;26(3):649-59. https://doi.org/10.5123/s1679-49742017000300022

23. Vargas MAJ. Lesões elementares. In: Sittart JAS, Pires MC, Lemos. Dermatologia para o clínico. São Paulo: 2 ed; 1998. p.405-7.

24. Petri V, Rotta O. Guias de medicina Ambulatorial/Hospitalar. UNIFESP. Escola Paulista de Medicina. São Paulo: Nestor Schor, Manole; 2007. Lesões elementares; p.1-7.

25. Lupi O, Boleira M. Dermatologia fundamental. Rio de Janeiro: Grupo Gen; 2013. Lesões elementares; p.1-12.

26. Azulay RD, Azulay DR, Abulafia LA. Azulay Dermatologia. Rio de Janeiro: Guanabara Koogan; 2015. Semiologia Dermatológica; p.52-72.

27. Rivitti EA. Dermatologia de Sampaio e Rivitti. São Paulo: Artes Médicas; 2018. A observação dermatológica: semiologia e glossários dermatológicos; p.108-17.

28. Cardili RN, Roselino AM. Elementary lesions in dermatological semiology: literature review. An Bras Dermatol. 2016;91(5):629-33. https://doi. org/10.1590/abd1806-4841.20164931

29. Musayón-Oblitas FY, Cárcamo CP, Gimbel S, Echevarría Jl, Graña AB. Validation of a counseling guide for adherence to antiretroviral therapy using implementation science. Rev Latino-Am Enfermagem. 2020;28:e3228. https://doi.org/10.1590/1518-8345.3117.3228

30. Sena JF, Silva IP, Lucena SKP, Oliveira ACS, Costa IKF. Validation of educational material for the care of people with intestinal stoma. Rev Latino-Am Enfermagem. 2020;28:e3269 https://doi.org/10.1590/1518-8345.3179.3269

31. Pierotti I, Fonseca LF, Nascimento LA, Rossetto EG, Furuya RK. Elaboration, validation and reliability of the safety protocol for pediatric thirst management. Rev Latino-Am Enfermagem. 2020;28:e3321. https://doi.org/10.1590/1518-8345.3333.3321

32. Miranda FBG, Mazzo A, Pereira-Jr GA. Construction and validation of competency frameworks for the training of nurses in emergencies. Rev Latino-Am Enfermagem. 2018;26:e3061. https://doi.org/10.1590/1518-8345.2631-3061

33. Lemos CS, Poveda VB, Peniche ACG. Construction and validation of a nursing care protocol in anesthesia. Rev Latino-Am Enfermagem. 2017;25:e2952 https://doi.org/10.1590/1518-8345.2143.2952

34. Rodrigues LN, Santos AS, Gomes PPS, Silva WCP, Chaves EM. Construction and validation of an educational booklet on care for children with gastrostomy. Rev Bras Enferm. 2020;73(3):e20190108. https://doi.org/10.1590/0034-7167-2019-0108

35. Jesus GJ, Caliari JS, Oliveira LB, Queiroz AAFLN, Figueiredo RM, Reis RK. Construction and validation of educational material for the health promotion of individuals with HIV. Rev Latino-Am Enfermagem. 2020;28:e332. https://doi.org/10.1590/1518-8345.3748.3322

36. Lopes JL, Baptista RCN, Domingues TAM, OhI RIB, Barros ALBL. Development and validation of a video on bed baths. Rev Latino-Am Enfermagem. 2020;28:e3329. https://doi.org/10.1590/1518-8345.3655.3329

37. Silva DI, Mello DF, Takahashi RF, Hollist CS, Mazza VA, Veríssimo MLOR. Validation of vulnerability markers of dysfunctions in the socioemotional development of infants. Rev Latino-Am Enfermagem. 2018;26:e3087. https://doi.org/10.1590/1518-8345.2736.3087

38. Lazarini LF, Ohler L, Schirmer J, Roza BA. Validation of the American Quality Assessment Model and Performance Improvement to the Brazilian transplant. Rev Latino-Am Enfermagem. 2020;28:e3252. https://doi.org/10.1590/1518-8345.3249.3252

39. Chaves FA, Cecilio SG, Reis IA, Pagano AS, Torres HC. Translation and cross-cultural adaptation of the Behavior Change Protocol for educational practices in Diabetes Mellitus. Rev Latino-Am Enfermagem. 2019;27:e3164. https://doi.org/10.1590/1518-8345.2908-3164

40. Galindo-Neto NM, Alexandre ACS, Barros LM, Sá GGM, Carvalho KM, Caetano JÁ. Creation and validation of an educational video for deaf people about cardiopulmonary resuscitation. Rev Latino-Am Enfermagem. 2019;27:e3130. https://doi.org/10.1590/1518-8345.2765.3130 
41. Saraiva NCG, Medeiros CCM, Araujo TL. Serial album validation for promotion of infant body weight control. Rev Latino-Am Enfermagem. 2018;26:e2998. https://doi.org/10.1590/1518-8345.2194.2998

42. Maciel MED, Vargas D. Cultural adaptation and content validation of the Single-Question for screening alcohol abuse. Rev Esc Enferm USP. 2017:e03292. https://doi.org/10.1590/s1980-220×2016048703292

43. Azevedo SB, Lima MLLT, Griz SMS, Leal LP. Instrument for evaluating child hearing health services: construction and validity. Rev Esc Enferm USP. 2018;52:e03357. https://doi.org/10.1590/s1980-220x2017036703357

44. Passinho RS, Primo CC, Fioresi M, Nóbrega MML, Brandão MAG, Romero WG. Elaboration and validation of an ICNP ${ }^{\circledR}$ terminology subset for patients with acute myocardial infarction. Rev Esc Enferm USP. 2019;53:e03442. https://doi.org/10.1590/s1980-220×2018000603442

45. Vanbelle S. A new interpretation of the weighted kappa coefficients. Psychometrika. 2016;81(2):399-410. https://doi.org/10.1007/ s11336-014-9439-4

46. Clay BW, Hoover K. The Breastfeeding Atlas. LactNews Press; 2008.

47. Kumar V, Abbas AK, Fausto N, Aster JC. Robbins \& Cotran. Patologia. Bases Patológicas das Doenças. Rio de Janeiro: Elsevier; 2010. 